\title{
Economic impact analysis of natural gas development and the
}

\section{policy implications}

\author{
P.N.K. De Silva ${ }^{1, *}$, S.J.R. Simons ${ }^{1}$ and P. Stevens ${ }^{2}$ \\ ${ }^{1}$ International Energy Policy Institute, UCL Australia, University College London, 220 Victoria Square, \\ Adelaide 5000, Australia; n.desilva@ucl.ac.uk ;+61 881109991 \\ ${ }^{2}$ Royal Institute of International Affairs, Chatham House, 10 St James's Square \\ London.
}

\section{Abstract}

In the US, the shale gas revolution ensured that the development costs of unconventional natural gas plummeted to the levels of $\$ 2-\$ 3 / \mathrm{Mcf}$. This success has motivated the development of shale gas in other regions, including Australia and Europe. This study, focussing primarily on aspects of economic impact analysis, estimates the development costs of shale gas extraction in both Australia and Europe, based on both direct and fiscal costs, and also suggests policy initiatives.

The increasing liquefied natural gas (LNG) developments in Australia are already straining domestic gas supplies. Hence, the development of more natural gas resources has been given a high priority. However, a majority of the Australian shale resources is non-marine in origin and significantly different to the marine-type shales in the US. In addition, the challenges of high development costs and the lack of infrastructure, service capacity and effective government policy are inhibiting shale gas development. Increasing the attractiveness of low risk investment by new, local, developers is critical for Australian shale gas success, which will simultaneously increase domestic gas security. In the European context, unconventional 
gas development will be challenged by direct, rather than fiscal costs. High direct costs will translate into average overall gas development costs over $\$ 13 / \mathrm{Mcf}$, which is well over the existing market price.

Keywords: Unconventional gas, Development costs, Shale gas, LNG

\subsection{Introduction}

The global energy sector is confronted with soaring energy needs of a growing population, improving standards of living and expanding economies of the world. Global energy consumption is projected to rise by $41 \%$ over the next two decades, while fossil fuels will still remain as the dominant form of energy, supplying around $80 \%$ of world energy consumption in 2040 (BP, 2014). Under this prolonged dependence on fossil fuels in conjunction with intensifying global concerns of increasing carbon emissions and climate warming, natural gas is becoming an important resource in catering to global energy needs. The International Energy Agency (IEA) (2014) asserts that world's remaining recoverable gas resources are sufficient for over 230 years at the current production rates. Moreover, natural gas is the fuel of choice for power generation as gas-fired power plants have the lower capital costs with less than half of the $\mathrm{CO}_{2}$ emissions of coal-fired power plants (Dormer, 2013; EIA, 2014a; Tay, 2014).

In addition, the emergence of unconventional oil and gas has added a whole new dimension to the fossil fuel industry. The term "unconventional" refers to the requirement of some form of reservoir stimulation, which makes the recovery process more complex. The stimulation process is referred to as hydraulic fracturing, which leads to an increase in the permeability of the underground geological formations, such as shale, that are holding the oil and gas, easing the hydrocarbons out of entrapment and towards the well bore and, subsequently, the wellhead. The success of hydraulic fracturing and horizontal drilling has contributed 
immensely to boosting the commerciality of low permeable oil and gas reservoirs that were previously identified as being non-economical to produce. The US shale gas revolution has also benefited from the favourable geology, availability of infrastructure, private mineral ownership, high liquid (oil) content, increased participation of small scale independent developers and less community resistance (Stevens, 2012). Motivated by the US success, many other countries around the world are trying to capitalise on shale oil and gas development. However, there are substantial differences in the geological, political, social and industrial situations elsewhere, compared to the US context.

Putting aside the political incentives for such development and the not unreasonable argument that we should no longer be seeking new fossil fuel reserves if we are to mitigate climate change (McGlade and Ekins, 2015), any consideration to develop an unconventional oil and gas sector must also include an economic impact analysis that takes into account all technical, regulatory, policy and infrastructure requirements to support such an industry. Such an analysis is the subject of this paper, in relation to shale gas development only.

\subsection{Shale Gas Developments in Australia and Europe}

The term 'unconventional gas' refers mainly to shale gas, coal seam gas, hydrates and tight gas resources (ACOLA, 2013), the distinction being made as to the various formations from which they are extracted, such as coal and shale. Methane hydrates are developed through depressurisation, by drilling well bores and stimulation through sound waves and/or chemicals to release entrapped methane gas (Garratt, 2012). While conventional gas can be recovered by using traditional drilling techniques, unconventional gas recovery requires additional stimulation, mainly in the form of hydraulic fracturing. Hydraulic fracturing is a process of injecting high pressure fluids into the formation, consisting of water, proppants (sand or ceramic particles to prop open fractures) and chemicals (AEA, 2012), which all need 
to be delivered from the well-head, adding to the complexity of the shale gas development process. In the US, shale gas reservoirs, or plays, are most commonly of marine origin. However, in Australia and Europe, Poland in particular, most of the shale plays are nonmarine in origin (EIA, 2013). Reservoir characterisation based on the total organic content (TOC), thermal maturity, gas content and brittleness is important in order to understand the production potential of these shale plays. Thus, geology and economics are the most critical elements that will need to be understood in the shale gas development process. It should be noted that, as yet, there are no commercially proven non-marine shale plays anywhere in the world.

\subsection{Australia}

The EIA has estimated Australian shale gas resources to be around 437 Tcf, mainly held in six reservoir basins (Table1) (EIA 2013). However, the challenging geology, lack of infrastructure and service sector and community concerns has resulted in high development costs. Therefore, the evaluation of reserves, which is an estimate of the amount of hydrocarbons that both technically and economically be expected to be produced will be critical (Deparment of Energy and Climate Change, 2013). The Australian east and west coast gas markets are currently focused on the export of LNG to Asia, due to Australia's strategic location and the Asian gas-price premium. This has resulted in the domestic gas price reaching parity with the export price, which, although undesirable, may make some of the shale gas plays economically viable to develop. Nevertheless, whilst the Australian LNG projects have the advantage of lower transportation costs to the Asian markets compared to the US, the increasing costs of offshore natural gas extraction projects will make maintaining this competitiveness challenging, as those countries with lower development costs and higher market efficiencies, such as the US, begin to export cheaper LNG. Unless there is an 
extensive demand growth from the Asian countries, the higher costs will reduce the attractiveness of Australian LNG exports in the future.

Table 1: Australian reservoir basins with estimated technically recoverable resources (EIA, 2013)

\begin{tabular}{|l|c|}
\hline Basin & Technically Recoverable (Tcf) \\
\hline Cooper & 93 \\
\hline Maryborough & 19 \\
\hline Perth & 33 \\
\hline Canning & 235 \\
\hline Georgina & 13 \\
\hline Beetaloo & 44 \\
\hline
\end{tabular}

\subsection{Europe}

In Europe, energy security is becoming of prime concern. The recent political unrest in the Crimea has led to an increase in interest in shale gas development (EURACTIV, 2014), particularly in Poland and the UK. The Ukraine, with 148 Tcf of technically recoverable resources, is preparing to initiate shale gas development to reduce its dependency on Russian gas imports. In contrast, some European countries have moratoria in place on hydraulic fracturing, such as France, Bulgaria and Germany, deterring any shale gas development plans. Even in Poland and the UK, full scale development of shale gas is at least 5-10 years away. At least 100 shale gas wells will be needed in each country to understand the commercial potential of these resources. In the European context, aside from the challenges of public opposition and concerns over inconsistent regulation and property rights, the key factor deterring investment is the direct development costs (Uliasz-Misiak et al., 2014). 
Poland and the UK have introduced attractive fiscal policy regimes for shale gas developments for both the developers and affected communities. Table 2 lists the European shale gas resources as estimated by EIA in 2013, along with the energy security rankings. The energy security rankings reflect the need for more energy resources (the higher the number, the more urgent the need). Thus, shale gas could become one of the most viable resources to increase energy security in Europe.

Table 2: European energy security rankings and technically recoverable shale gas resources (EIA, 2013; World Energy Council, 2014)

\begin{tabular}{|l|c|}
\hline European countries / Energy & Technically Recoverable (Tcf) \\
security rank & 285 \\
\hline Russia (2) & 148 \\
\hline Ukraine (54) & 145 \\
\hline Poland (32) & 136 \\
\hline France (41) & 37 \\
\hline Romania/Bulgaria (4/24) & 26 \\
\hline UK (9) & 26 \\
\hline Netherlands (55) & 17 \\
\hline Germany (27) & 10 \\
\hline Sweden (20) & 8 \\
\hline Spain (37) & 2 \\
\hline Lithuania/Kaliningrad (90) & \\
\hline
\end{tabular}

The following sections describe the current state of shale gas development commitments in Poland and the UK. 


\subsubsection{Poland}

To date, Poland has been successful in drilling about 40 exploration wells. Furthermore, there has been a great deal of encouragement from the government in the form of direct investment and tax incentives up to 2020. However, Poland suffered major setbacks in its bid to develop its shale gas resources, with the subsequent departure of two major international companies, namely, Exxon Mobil (in 2011) and Total (in 2013) (Natural Gas Europe, 2012, 2014). This was not an encouraging sign, since both companies highlighted the complexity of Polish shale geology, which is very deep, and the associated concerns over the high pressures and temperatures leading to reductions in the commercial potential of these shale plays, as behind their decisions to pull out. The hopes for development success now rest mainly with Chevron and Conoco Philips.

\subsubsection{UK}

Cuadrilla Resources has been active in shale gas development in the UK since 2010 (Selley, 2012). However, the company suffered a major setback, when minor earthquakes were triggered in the Blackpool area, possibly related to their hydro fracturing activities (hydrofracking may act to lubricate active fault planes with stimulation fluids) (Mobbs, 2012). Fracking could stimulate minor earthquakes up to a magnitude of 3 on the Richter scale (AEA, 2012). According to Ohio Department of Natural Resources, an earthquake could be caused due to the nearby faults at near-failure state of stress (ODNR, 2012).

In Sussex and Scotland, there are plans to develop shale oil and gas by IGAS Energy, Cuadrilla Resources, INEOS and Celtique Energie. However, in both regions, potential shale development plans has been met with severe community resistance. This led to impose a ban on fracking for shale gas in Scotland in early 2015 (CityA.M., 2015). The UK government is becoming more proactive in recognising the importance of shale gas for energy security and the potential to create jobs (UK Government, 2013), although other commentators doubt the 
scale of the impact, given the rather low level of technically recoverable resources, as shown in Table 1 (McGlade and Ekins, 2015). Until now, only the Bowland basin is being tested for shale gas development, with four exploratory wells drilled by Cuadrilla Resources and another drilled by IGAS Energy.

3.0 Economic Impact Analysis

\subsection{Methodology}

In this study, the economic impact analysis of unconventional gas resource development has been evaluated for Australia and Europe. Data inputs, such as the drilling and completion costs, royalties, income taxes, operational and other fiscal costs were used to estimate the costs involved in the development. Then, a sensitivity analysis was conducted to assess the effect of the major cost components on the breakeven gas price, followed by an annual Discounted Cash Flow analysis (DCA) to evaluate the potential of unconventional gas development in Australia and Europe. This study will contribute to the understanding of the market conditions necessary to commercially develop shale gas resources. The estimated ultimate recovery (EUR) of a shale gas well represents the accumulated sum of the gas produced throughout the well life. However, the EUR is subject to the Geology, Geomechanics and Petrophysical conditions of the formation, influencing the Initial Production (IP) and the decline of the gas production over time. The analysis in this study will consider IP and decline data that are currently available for a limited number of Australian test wells listed in Table 3. 
Table 3: Tests shale wells in the Cooper basin of South Australia (Beach Energy, 2011a, b; Tedesco, 2012)

\begin{tabular}{|l|l|l|l|l|l|}
\hline Vertical Well & $\begin{array}{l}\text { Initial } \\
\text { Production } \\
(\text { IP) (mmscf) }\end{array}$ & $\begin{array}{l}\text { Well Cost } \\
(\text { million \$) }\end{array}$ & $\begin{array}{l}\text { Completion } \\
\text { time (days) }\end{array}$ & $\begin{array}{l}\text { Depth } \\
(\mathbf{m})\end{array}$ & $\begin{array}{l}\text { Frack } \\
\text { stages }\end{array}$ \\
\hline Moomba-191 & 3,000 & 10 & 26 & 3,010 & 3 \\
\hline Holdfast-1 & 2,000 & N/A & 78 & 3,487 & 7 \\
\hline Encounter-1 & 2,000 & N/A & 82 & 3,612 & 6 \\
\hline
\end{tabular}

A study conducted by Weijermars (2013) adopted a Discounted Cash Flow methodology to compare the economic viability of several shale gas plays in Continental Europe. The assumptions that were used include a uniform field development plan of 100 wells at 10 wells/year over a decade. The DCA analysis was done based on the prevailing technological costs to estimate the EUR that needs to be achieved for these projects to become viable. Other factors relevant to the DCA are gas prices, taxes, depreciation and discount rate. These factors were simulated for different EUR values, where the sensitivity of Net Present Value (NPV) and Internal Rate of Return (IRR) to EUR were modelled for each play. Assessment of risks was done by simulating the spread of the NPV and IRR against the spatial spread of production volume probabilities P10-P50-P90. This study adopts a similar methodology to compare the Australian and European shale plays with the US shale plays. Further, inbuilt Visual Basic programming functions of Microsoft Excel for cash flow modelling are used based on the annual averaged gas price projections and annual production volumes of a typical well. The annual non-discounted cash balance (A) is estimated with the following equation: 
Equation 1: Annual non-discounted cash balance

$\mathrm{A}=(\mathrm{P} \times \mathrm{Q})-$ Capex - Opex $-\left(\mathrm{C}_{\mathrm{R}} \times \mathrm{P} \times \mathrm{Q}\right)-\left(\mathrm{C}_{\mathrm{T}} \times\right.$ Income $)$

Where:

$\mathrm{P}=$ Price of gas at the wellhead

$\mathrm{Q}=$ Annual production

$\mathrm{C}_{\mathrm{R}}=$ Royalty rate

$\mathrm{C}_{\mathrm{T}}=$ Corporate tax rate

The revenue stream (income) is estimated by:

Equation 2: Revenue

Income $=(P \times Q)\left(1-C_{R}\right)-$ Opex $-D($ Capex $)$

Where:

$\mathrm{D}=$ Depreciation rate of Capex.

The net present value (NPV) is estimated by:

Equation 3: Net Present Value

$\mathrm{NPV}=\sum\left(\frac{A_{t}}{(1+F)^{2}}\right)$

Where:

$\mathrm{F}=$ Annual discount factor to account for time value of money over the duration from the year $\mathrm{t}=0$ to $\mathrm{t}=\mathrm{n}$. 
As an important input to derive the revenue, an inflation function price algorithm is used (Weijermars, 2013):

Equation 4: Price with inflation

$\mathrm{p}_{\mathrm{n}}=\mathrm{p}_{\mathrm{i}}(1+\mathrm{r})^{\mathrm{n}}$

Where:

$\mathrm{p}_{\mathrm{n}}=$ Wellhead gas price in year $\mathrm{n}$

$\mathrm{p}_{\mathrm{i}}=$ Initial gas price

$\mathrm{r}=$ Annual inflation rate affecting gas price.

\subsubsection{Well Productivity}

Geology and Petrophysics are critical in evaluating suitable shale plays for exploration and development. Binnion (2012) mentioned that due to the complexity of geological plays, especially variations in in-situ stresses, even two wells in close proximity and a horizontal well at different stages can produce very different results (Binnion, 2012). Thus, studying any potential shale play leads to a long term learning curve that could only be refined by repeating the tests to acquire a sufficient dataset enabling statistically significant set of results.

The well flow rates and corresponding cumulative production over the assumed 15 year well life was derived by fitting the equation to the estimated EUR data.

Equation 5: Estimated Ultimate Recovery

$\mathrm{q}_{\mathrm{n}}=\mathrm{q}_{\mathrm{i}}(1+\mathrm{a})^{\mathrm{n}}$

Where: 
$\mathrm{q}_{\mathrm{n}}=$ Flow rate in year $\mathrm{n}$

$\mathrm{q}_{\mathrm{i}}=$ Initial flow rate in year 1

$\mathrm{a}=$ Annual decline rate (a negative fraction)

The initial rate of production and the well decline rate are also different from one well to another (ACOLA, 2013). Therefore, the productivity of a play should ideally be taken as the aggregate production from all wells and the aggregated probabilistic range of the production will be the determinant for the required selling price of gas for the investment to become viable. This is based on the observation from the US shale plays, where the production of an individual well is somewhat uncertain, but aggregated investment in multiple wells provides a relative certainty to the production rates in the long run.

\subsubsection{Arp's decline function}

Decline curve analysis is time tested and established engineering technique to determine the rate of production decline in oil \& gas wells. Arps (1945) established the production decline curves by using empirical equations that grouped three most observable types of decline curves as exponential, hyperbolic and harmonic. The Arps well's production rate (q) at time t is as follows:

Equation 6: Arp's well production rate

$$
q=q_{i} \frac{1}{\left(1+b D_{i} t\right)^{\left(\frac{1}{b}\right)}}
$$

Where:

$\mathrm{q}_{\mathrm{i}}=$ Well's production rate at time 0

$\mathrm{D}_{\mathrm{i}}=$ Initial nominal exponential decline rate 
$\mathrm{b}=$ Hyperbolic exponent

A Shale gas well could be transformed from hyperbolic to exponential decline due to the changes of flow regimes. Shale reservoirs with transient flow regimes reach that stage in years as compared to the conventional wells that takes only months. Transient flow regime is caused by the flow of tight gas from fractures, tight zones or horizontal sections (Ryder Scott, 2011). The $b$ value (a measure of loss ratio for the production, between 0 and 1 ) defined by Arp's does not exactly match with the actual field observations in shale plays where b value can reach as high as 2 . However, a high $\mathrm{b}$ value tends to generate higher EUR than the actual value, especially in the early stages of production, as the value of $b$ tend to diminish with time. In most cases, a D min value (the minimum decline final segment) is used at the exponential tail part of the curve, which can last up to 15 years in order to accurately derive at the right EUR for shale plays. Overstating the D min tends to underestimate the EUR while giving a D min that is too low can overestimate the reserves (Ryder Scott, 2011). Therefore, Arp's method uses two segment analysis, those are the hyperbolic part, and the exponential tail end part of the curve to demonstrate the transient to boundary-dominated flow. It is important to note that the minimum ultimate decline rate is best found from the analogous reservoirs with long histories. Unfortunately, the required long-term observation to create the analogy is widely absent with emerging shale plays. In the absence of well-established values for both Australia and Europe, decline curves over the estimated well life are forecasted based on the average D and b values corresponding to the US plays (Table 4). 
Table 4: D \& b values of US shale wells (ACOLA, 2013)

\begin{tabular}{|c|c|c|c|c|c|c|}
\hline & Haynesville & $\begin{array}{c}\text { Eagle } \\
\text { Ford }\end{array}$ & Woodford & Marcellus & Fayatteville & Australia \\
\hline IP(mmscfd) & 1690 & 1160 & 730 & 446 & 420 & 3000 \\
\hline D & 0.81 & 0.77 & 0.93 & 0.9 & 0.9 & 0.86 \\
\hline b & 0.01 & 0.02 & 0.51 & 0.56 & 0.47 & 0.31 \\
\hline
\end{tabular}

\subsubsection{Fiscal costs}

ACOLA (2013) made comparisons between attributes of the US and Australian shale gas fiscal policy regimes. The main difference among the US and Australian taxation system is that the royalty in the US is directly paid to the private landowners (percentage of revenue normally between $12.5 \%$ and $25 \%$ ), whereas respective state receives income in terms of a Severance Tax (calculation base differ for respective states). Corporate income tax (CIT) is payable to the US Federal government and state governments, whereby the Federal government receives $35 \%$, whereas state government receive between $0 \%-12 \%$ (calculated based on EBIT). In the Australian context, developers are liable to pay the royalties and Petroleum Resources Rent Tax (PRRT) to the state governments and Federal government respectively. Royalty is payable to the state government, where resources are located based on the difference of the gross value at the wellhead and costs incurred to transport the gas to the point of sale (at the rate of $10 \%$ for the Cooper Basin in South Australia) and credited against PRRT, whereas PRRT is payable to the Commonwealth government, calculated as a percentage of the taxable profit $(40 \%)$. The CIT for Australia is based on the net earnings, after PRRT deduction and depreciation of asset, calculated at $30 \%$ of EBIT. The analysis of 
Australian cash flow of shale resource development project is subject to the following fiscal conditions:

Equation 7: State Royalties

Royalty $=$ Wellhead gas price $\mathrm{x}$ Volume produced $\mathrm{x}$ rate $(10 \%$ assumed for all basins $)$

Equation 8: Petroleum Resource Rent Tax (PRRT) to the Federal Government

PRRT = Taxable profit $\mathrm{x} 40 \%$

$=($ assessable receipt - deductible expenditure $) \times 40 \%$

Royalties paid to the state government can be credited against PRRT

Depreciation

Depreciation of an asset is used for corporate income tax deductions, since asset will decline in value over their effective life (EY, 2013). Depreciation of an asset in Australia is spread over the estimated useful life of the asset and the operator can get to choose between the 'diminishing value' (DV) or 'prime cost' (PC) depreciation method deemed to best suit the economic activity.

Equation 9: Prime cost depreciation

Depreciation $=$ Asset's cost $X \frac{\text { days held }}{365} \times \frac{100 \%}{\text { asset's effective life }}$

Where:

Asset's cost $\quad=\quad$ CAPEX

Asset's effective life $=\quad$ Assumed to be 15 years in this analysis 
The diminishing value method is where the asset decreases more in value in the early years and less in the later years, whereas the prime cost method assumes uniform depreciation of asset throughout the entire life of the asset (ATO, 2013). The formula for this method is:

Equation 10: Diminishing value depreciation

Depreciation $=$ Base value $X \frac{\text { days held }}{365} X \frac{200 \%}{\text { asset's effective life }}$

Where:

Base value $=$ CAPEX for the $1^{\text {st }}$ year and CAPEX minus the cumulative depreciation of the asset in the previous year/s, for the $2^{\text {nd }}$ year onwards

The diminishing value method gives a higher amount of depreciation in the early years of the asset's life. Some investors prefer this method over the prime cost method unless the expected revenue will increase substantially in the later years. For example, in the real estate industry, property investors use the prime cost method as the loss of value is more uniform in fact for their advantage, and properties doesn't just loose the value within the initial years.

Equation 11: Corporate Income Tax (CIT)

CIT = Taxable income $\times 30 \%$

Taxable income is the income received minus all other deductions expended in the process of generating the income, including state royalty, PRRT and depreciation in asset.

Similarly, European fiscal costs are estimated based on the attributes listed in the Table 7. 


\subsection{Analysis}

Table 5 compares the development costs for Australia and Europe with those of the US. In this analysis, the estimation of European shale gas costs does not consider petroleum revenue tax and ring-fenced corporation tax that is applicable in the UK, as the UK government is considering large tax incentives for onshore shale gas development, bringing down the existing $62 \%$ tax applicable to conventional hydrocarbon operations to $32 \%$ for onshore shale gas fields (Mainwaring, 2013). In Poland, petroleum revenue taxes are not applicable, but already there are proposals to impose such taxes (Meurs, 2012). For European shale gas developments, a uniform depreciation of $10 \%$ has been assumed.

Table 5. Comparison of the fiscal and development costs of the US, Europe and Australia (EY, 2013; Weijermars, 2013)

\begin{tabular}{|c|c|c|}
\hline United States & Australia & Europe \\
\hline Royalty $(12.5 \%-30 \%)-$ Private & Royalty $(10 \%-12.5 \%)-$ State revenue & Royalty $(0 \%-13 \%)$ \\
\hline Based on value of petroleum & May be credited against PRRT & - Crown \\
\hline Income tax & Income tax & Income tax \\
\hline Federal) $+(0-12 \%$ State) & Earnings before interest and tax *30\% & 19\% - 30\% \\
\hline Severance tax & Petroleum resource rent tax (PRRT) & N/A \\
\hline Up to 5\% of revenue & PRRT Taxable profit * 40\% & Land leasehold costs \\
\hline Leasehold costs & Land lease costs (State) + Native lands & Up to 1-3\% of revenue \\
\hline \$5,000 per acre & Up to 1-2\% of revenue & Depreciation \\
\hline Depreciation & Diminishing value or Prime cost & Uniform depreciation \\
\hline Dring and lease costs & Depreciation & \\
\hline
\end{tabular}


Drilling and completion costs

$\$ 3.5$ to $\$ 7.0 \mathrm{M}$ per well

Operating costs

$\$ 0.50$ to $\$ 1.00 / \mathrm{Mcf}$
Drilling and completion costs

$\$ 12-16$ M per well

Operating costs

$\$ 1.00 / \mathrm{Mcf}$
Drilling and

completion costs

\$ 8-24.5 M per well

Operating costs

$\$ 0.4-1.2 / \mathrm{Mcf}$

\subsubsection{Australia}

In the Australian context, the choice as to whether or not to develop a shale gas resource is predominantly dependent on the direct development costs, more so than the domestic gas price, which was one of the underpinning factors of the US shale gas revolution (Stevens, 2010). The availability of other cheaper natural gas resources, in the forms of onshore conventional, offshore conventional and coal seam gas, is leading to the delay in commitments on shale gas assets. As reflected in the US shale gas revolution, shale plays require high activity levels and rapid well replacement procedures to benefit from the economies of scale. The distinctive difference of very much greater shale play depths (ca. 3-4000m) will require technological advances in hydro fracturing that will also delay any new investment. Therefore, shale gas development will need to be incentivised, particularly through the fiscal policy regime, to increase the attractiveness of investment. This could be achieved through rapid depreciation policies, a decrease in Petroleum Resource Rent Tax (PRRT) and royalty payments and income tax holidays. This would then make it attractive for local small scale developers to "learn by doing", leading to more partnership agreements with customers, such as that between Strike energy and Orica for a to 20 year supply of gas (Stevens et al., 2013). Increasing the attractiveness of shale gas development for Australian 
small scale developers could lead to not only an increase in the energy security of Australia, but also the development of a strategic service sector (and the subsequent job opportunities) that could capitalise on shale gas development in the Asian region.

Small-scale/ junior developers could be incentivised by a variety of mechanisms. Most importantly, long term sustainability of policy is vital for the industry. This study compares the single-well development using DCA for four alternative policy directions based on the current Australian context and a gas unit price of \$9.57/Mcf, namely:

1. $100 \%$ depreciation of exploration and development costs in the first year

2. 70\% depreciation of exploration and development costs in the first year, divided equally within the remaining well life (14 years)

3. PRRT holidays - first 3 years

4. PRRT holidays - first 5 years

Table 6 lists the parameters used in the analysis.

Table 6: Data table and DCA of an Australian shale well

\begin{tabular}{|l|c|}
\hline Drilling and Completion & $\$ 9,000,000$ \\
\hline State Royalties & $10 \%$ \\
\hline Well Spacing & 80 acres \\
\hline PRRT & $40 \%$ \\
\hline Income Tax & $30 \%$ \\
\hline Well life time & 15 years \\
\hline Discount rate & $10 \%$ \\
\hline
\end{tabular}




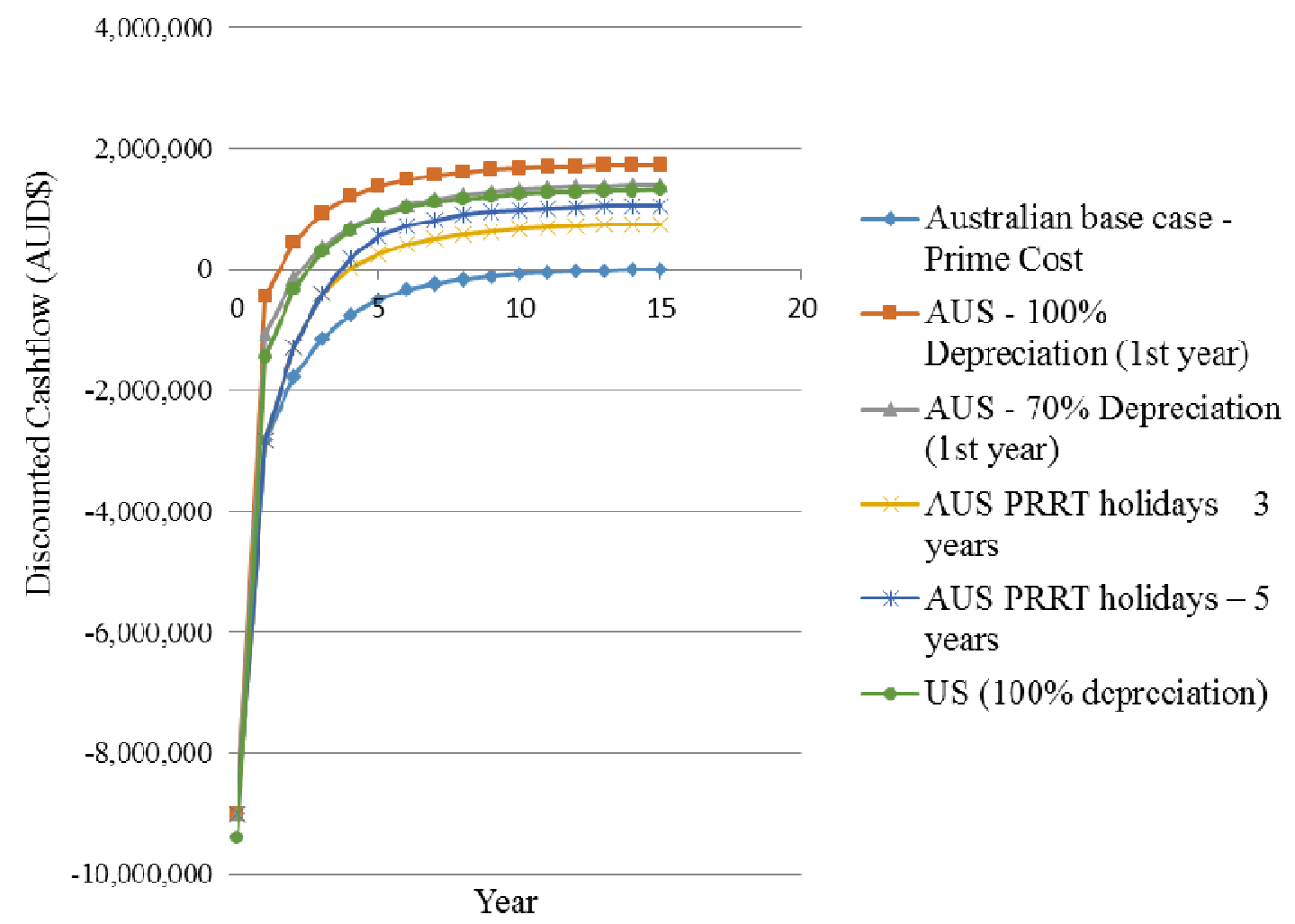

Figure 1. Annually Discounted Cash Flow of Australian shale gas developments based on fiscal policy incentives.

As depicted in Figure 1, 100\% depreciation of well drilling and completion costs has translated to a positive cash flow of $\$ 1,726,943$, with a total fiscal cost contribution of $\$ 5,675,401$ over the life-time of the well. Therefore, as depicted by these results and the US experience, this could become an attractive policy in encouraging further investment in shale gas development amongst small-scale developers. This would also be a more stable policy, especially since shale gas plays need rapid well replacement procedures. Thus, it will also be attractive for service companies, leading to higher economies of scale in the development, leading to lower gas development costs. 


\subsubsection{Europe}

In regards to Europe, direct development costs range from $\$ 8.1$ - $\$ 24.5$ million per well (Weijermars, 2013). As a result, the average gas unit price is approximately $\$ 13.32 / \mathrm{Mcf}$. Using this price and direct development costs of $\$ 16.3 \mathrm{M}$, it can be seen (Figure 2) that the US fiscal regime is much more favourable, due to the $100 \%$ depreciation of such costs (Table 7 lists the parameters used in this analysis). However, the fiscal cost regime in Europe is becoming more conducive to shale gas development. Poland has already committed to a six year corporate tax-free period until 2020. The UK has proposed funding to local councils who commit to shale gas developments (UK Government, 2014). Questions have been raised about the economic implications of this, and the exclusion of any returns to landowners, where lateral drilling takes place only a short distance away from the main vertical drilling. However, the main challenge to the shale gas industry is the excessive direct costs, which are much higher than in the US. These costs will need to come down substantially if a European shale gas revolution is to occur. Gas costs should ideally not be too high relative to Qatar LNG, or even in comparison to Australian and US LNG. The main obstacles lie with the materials, infrastructure and services required for shale gas developments. As mentioned previously, shale gas developments need rapid well replacement procedures and benefit from economies of large scale production, as reflected in the US experience. Therefore, the development plans for shale gas in Europe must specifically look into the direct costs. Hydro fracturing requires large volumes of water, as well as proppants and other ingredients, such as guar gum. Therefore, there should be considerations as to how to develop local supply chains for these essential materials to avoid any bottlenecks, since the industry will otherwise be dependent on imports from elsewhere, such as China for proppants and India for guar gum. Reliance on imported services will reduce the attractiveness of the industry, which already 
has to deal with community opposition and the challenges concerning inconsistent regulations across Europe.

Table 7: Data table and DCA of European shale gas developments

\begin{tabular}{|l|c|}
\hline Drilling and Completion Costs & $\$ 8,100,000-24,500,000$ \\
\hline State Royalties & $6.5 \%$ \\
\hline Well Spacing & 80 acres \\
\hline Income Tax & $25 \%$ \\
\hline Well life time & 15 years \\
\hline Discount rate & $10 \%$ \\
\hline
\end{tabular}

$10,000,000$

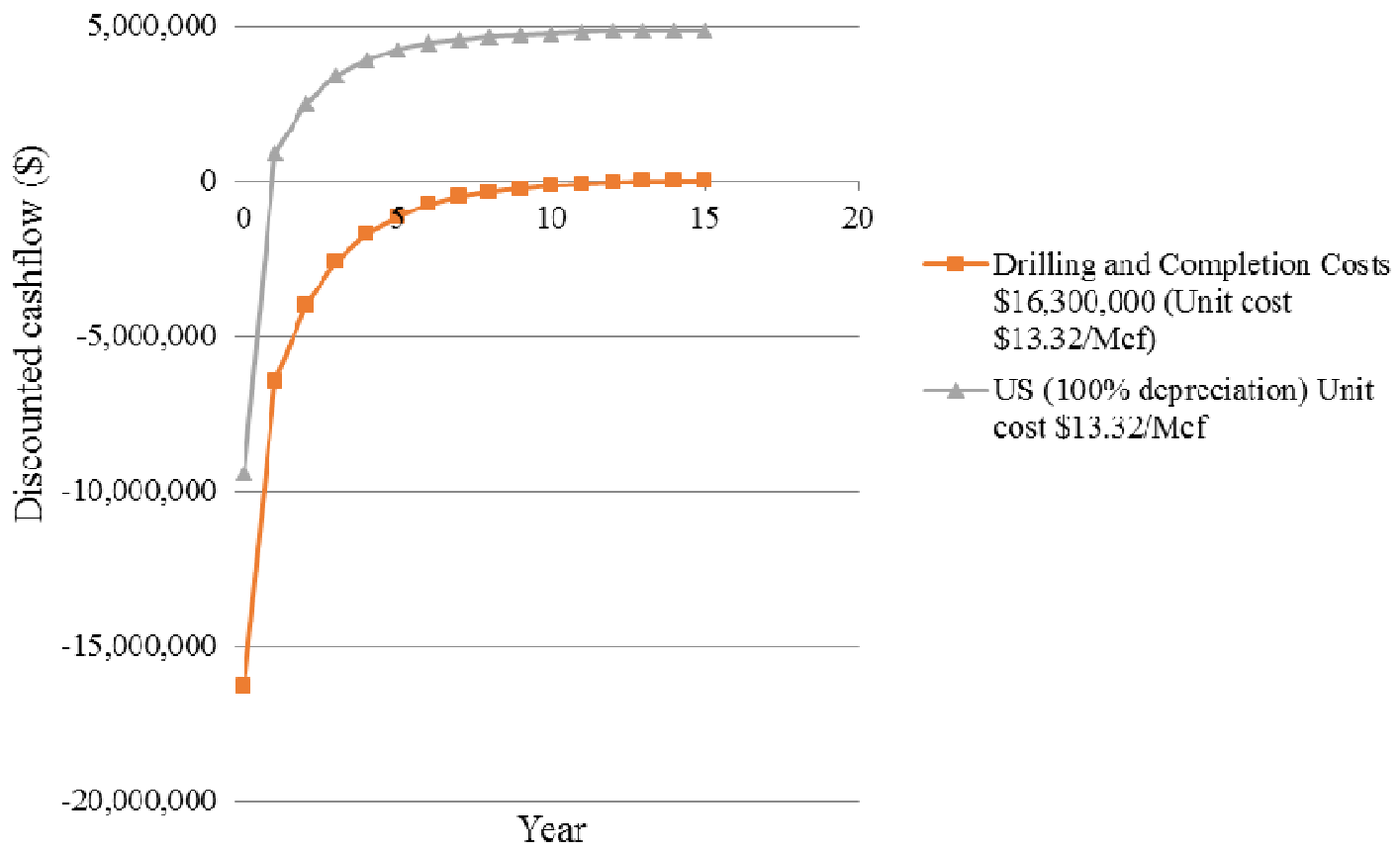

Figure 2. Comparison of DCA for Europe and the US based on a gas cost of \$13.32/Mcf 


\subsection{Shale Gas Development Factors}

The US shale gas revolution benefited from a multitude of factors (Table 8). However, the same cannot be said for shale gas development in Europe and Australia. The main factors, covering geology, infrastructure, environmental regulation and community acceptance, will now be discussed in more detail, followed by an analysis of the policy implications.

Table 8: Important factors for shale gas development in the US, EU and Australia

\begin{tabular}{|c|c|c|c|}
\hline Characteristics & US & EU & AUS \\
\hline Favourable geology & Yes & No & No \\
\hline Lots of drill core data to locate "Sweet spots" & Yes & No & Depends on the basin \\
\hline Weak environmental regulation for fracking & Yes & No & Depends on the state \\
\hline Tax credits + Intangible drilling cost expensing & Yes & No & No \\
\hline Property rights to the landowner & Yes & No & No \\
\hline $\begin{array}{l}\text { Pipeline access very easy - large network + } \\
\text { common carriage }\end{array}$ & Yes & No & No \\
\hline Selling gas into a "commodity supply" very easy & Yes & No & No \\
\hline Dynamic and competitive service industry & Yes & No & No \\
\hline Population familiar with oil and gas operations & Yes & No & Depends on the basin \\
\hline Licensing large areas with vague work programs & Yes & No & Depends on the state \\
\hline Significant government investment in R \& D & Yes & No & No \\
\hline High liquids content & Yes & No & Depends on the basin \\
\hline Started by rising gas prices and demand & Yes & No & No \\
\hline
\end{tabular}




\begin{tabular}{|lccc|}
\hline Access to favourable finance & Yes & No & No \\
\hline Investment on shared infrastructure & Yes & No & No \\
\hline
\end{tabular}

\subsection{Geological complexities}

In Australia and Europe, the lack of understanding of the lithology of the local shale formations and the recoverable resource content are challenging the prospective shale gas development plans. In particular, technology successfully applied in the US may need to be customized for the non-marine shale plays of Australia and Europe. As an illustration, Figure 3 compares the main geological parameters of the Cooper basin shales of South Australia with those in the US. It can be seen that there are distinct differences. The Cooper Basin shale plays, being non-marine in origin, are less brittle (higher clay content) and indicate much lower recoverable resource content (absorbed gas and TOC) (Regenauer-Lieb, 2014). In addition, these plays are dry (little or no liquid content) and have high carbon dioxide content, making development plans technically and economically challenging. Australian shale plays are also subjected to higher tectonic stresses compared to North American shale plays (ACOLA, 2013). Therefore, the effectiveness of using a similar technology to develop shale gas resources in Australia is uncertain, with no guarantee of long-term success.

In the US, advancement of Horizontal drilling in 2003 elevated the production level to a new level and launched the Barnett play shale development (EIA, 2011b), even though the technology was around for much longer (King, 1993). With the ability to drill through more shale rocks confined within a thin layer of formation spread over a wide area, the resulting wells are exposed to more formation volume as opposed to vertical wells. Vertical wells practically tap into a limited vertical formation volume, whereas the longest lateral of a horizontal well today could extends to over $3 \mathrm{~km}$, enabling access to a wider pay zone, immensely improving the economics (O'Brien, 2013). In the US, there was an exponential 
growth of horizontal shale wells, which led to increase the production of shale gas from $1 \mathrm{bcf} /$ day in 2003 to $5.5 \mathrm{bcf} /$ day in 2010 (EIA, 2011a, b). This is also benefited by the slick water based stimulation fluids replacing previously used gel-based stimulation fluids (Wang and Krupnick, 2013). Commercialization of the method benefited from the advances in down-hole motors and down-hole telemetry. In addition, longer drilling laterals were made possible along with the multi stage stimulation (Halliburton, 2008).

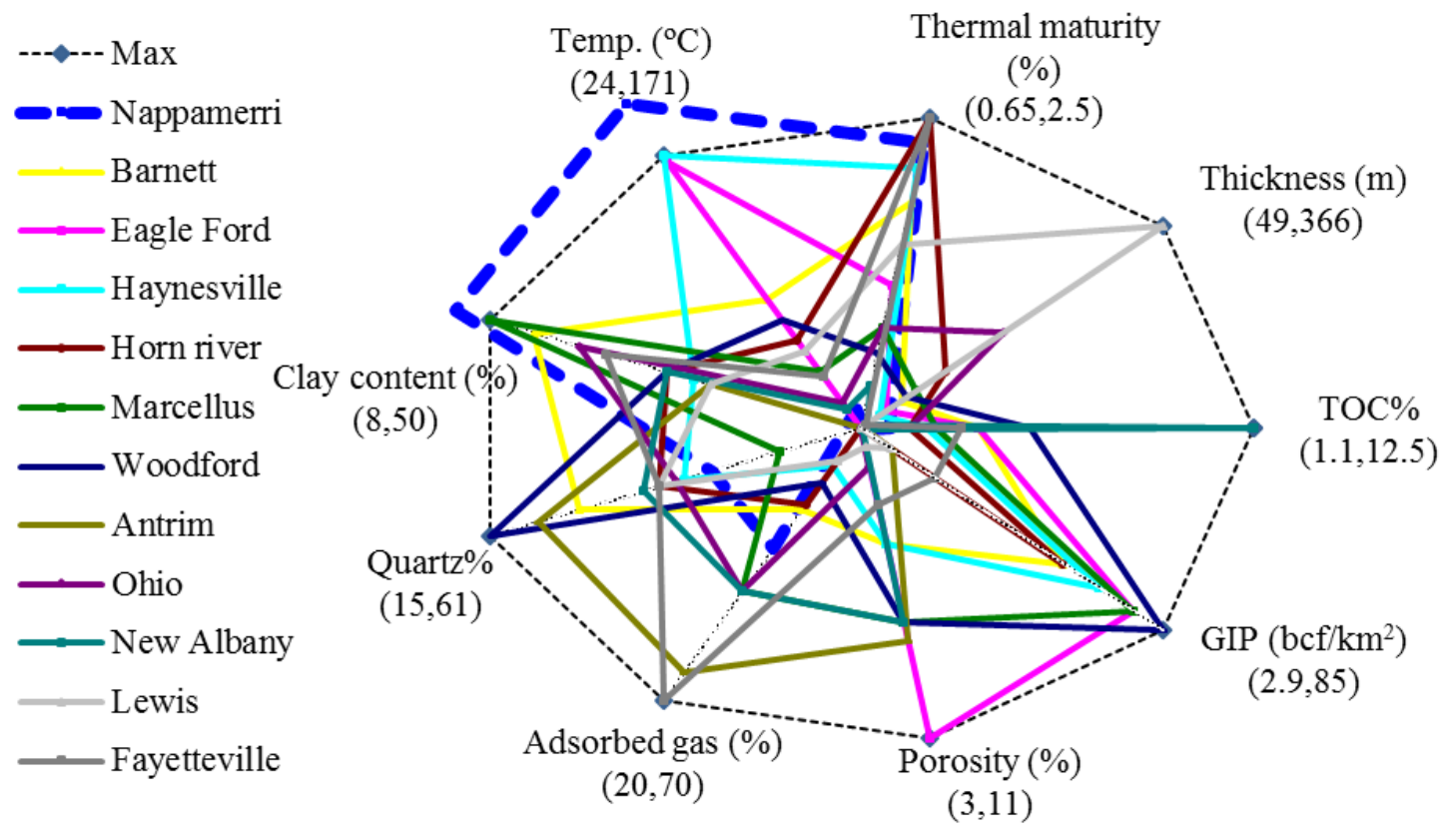

Figure 3. Comparison of Australian shale plays with the US shale plays (Agarawal et al., 2012; Cardott, 2006; Curtis, 2002; Hexion, 2009; Kulkarni, 2011; Mckeon, 2011; Patterson, 2012; Rajtar, 2010; Schulz and Horsfield, 2010; USDOE, 2009) 


\subsection{Infrastructure and accessibility}

Shale and tight gas developments require access to processing and transport infrastructure to refine and deliver the developed gas. However, in the initial phase, it will be challenging to develop such infrastructure, particularly in the remote regional areas of Australia, where sufficient gas or liquid recovery potential has yet to be proven. In comparison, the US already had a comprehensive gas pipeline network in place prior to shale gas development. As illustrated in Figure 4, although the US and Australia have a similar land area, the pipeline infrastructure is very different. In the US there are $480,000 \mathrm{~km}$ of natural gas transmission pipelines, compared to 25,000 km in Australia. Europe has around 200,000km (APIA, 2015; Papadakis, 2005). Furthermore, in Australia and Europe, most of the pipelines are regulated by contract carriage, compared to the common carriage model adopted for the interstate pipelines of the US. Therefore, third party access will not be straightforward to an already limited pipeline network. A significant increase in gas pipelines and easy access are important for independent developers to effectively participate in the shale gas development process.

Availability and shared access to pipelines and gas processing infrastructure have contributed significantly towards the shale gas revolution in the US. Figure 4 shows the potential Australian shale plays, along with the existing pipelines. While the infrastructure in the Cooper Basin is reasonably good, there are no pipelines connecting the Canning, Georgina, Pedrika and Officer Basins to the existing main transmission lines. Access is also constrained by the current regulatory regime for pipelines. Majority of the Australian gas pipelines are regulated through contracted carriage. To date, only six out of 14 major eastern gas transmission pipelines, two out of eight major western gas transmission lines and 10 distribution networks are fully regulated for third party access (SCER, 2013). In addition, the 
spread of other infrastructure, such as approach roads and processing plants (with shared access) are also vital to enhance the shale gas development potential of Australia.
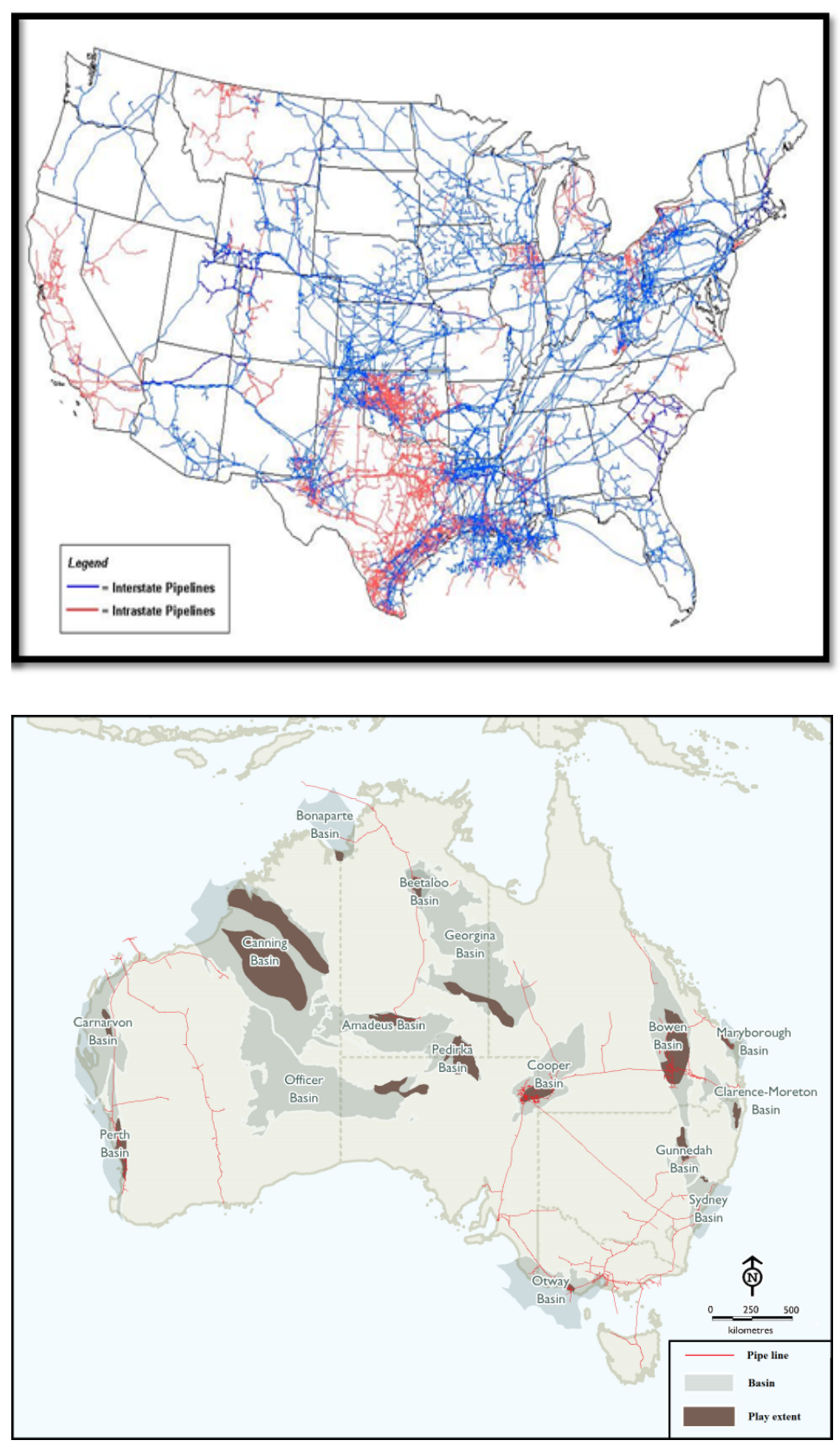

Figure 4. Comparison of Australia and US pipeline networks (EIA, 2014b; Rawsthorn, 2013) 
4.3 Environmental impact, regulations and community acceptance

Fracture stimulation uses about $10-20 \mathrm{ML}$ of water per well (Stevens et al., 2013). Out of the injected water, only up to $25 \%$ returns to the surface that require cleaning and treatment (Haluszczak et al., 2013). The water consumption in stimulation could be minimised by using waterless fracking mechanisms (Goodman, 2012). However, such technologies are still at infancy. Further, methane losses during the development of shale gas could contribute to increase climate concerns (Stamford and Azapagic, 2014). These losses are dependent on the local conditions such as the depth of exploration, permeability and wellbore integrity. Therefore, the implementation of best development practices in wellbore development and abandonment is critical to minimise such losses. Based on the previous studies, a comparison of Greenhouse gas emissions from conventional, unconventional natural gas development and coal is illustrated in the Tables $9-11$. Due to the associated methane emissions from upstream activities, unconventional gas development has shown similar greenhouse footprint as coal. 
Table 9: Life cycle Greenhouse gas emissions from conventional natural gas $\left(\mathrm{kg} \mathrm{CO}_{2}\right.$-e/kWh) (Agrawal et al., 2014; Burnham et al., 2012; Hardisty et al., 2012; Howarth, 2014; Jiang et al., 2011; PACE, 2009; Stephenson et al., 2011)

\begin{tabular}{|c|c|c|c|c|c|c|c|}
\hline \multirow{2}{*}{ Reference } & \multirow{2}{*}{ Region } & \multicolumn{4}{|c|}{ Greenhouse gas emissions } & \multirow{2}{*}{$\begin{array}{c}\text { Plant } \\
\text { efficienc } \\
\text { y }\end{array}$} & \multirow{2}{*}{$\begin{array}{c}\mathrm{CH}_{4} \\
\text { emission } \\
\text { rate }\end{array}$} \\
\hline & & $\begin{array}{l}\text { Life } \\
\text { cycle }\end{array}$ & $\begin{array}{c}\text { Upstrea } \\
\text { m }\end{array}$ & $\begin{array}{c}\text { Combustio } \\
\mathrm{n}\end{array}$ & $\begin{array}{l}\text { Liquefactio } \\
\text { n and } \\
\text { transport }\end{array}$ & & \\
\hline $\begin{array}{c}\text { Howarth, } \\
2014\end{array}$ & U.S & $\begin{array}{r}482 \sim 67 \\
5\end{array}$ & $108 \sim 301$ & 374 & & $41.8 \%$ & $\begin{array}{c}1.7 \% \sim 6 \\
\%\end{array}$ \\
\hline $\begin{array}{l}\text { Jiang et } \\
\text { al., } 2011\end{array}$ & U.S & 475 & 106 & 369 & & $50 \%$ & N/A \\
\hline $\begin{array}{c}\text { Burnham } \\
\text { et al., } \\
2012\end{array}$ & U.S & 635 & 167 & 468 & & $33.1 \%$ & $2.75 \%$ \\
\hline $\begin{array}{c}\text { Stephenso } \\
\text { n et al., } \\
2011\end{array}$ & U.S & 488 & 49 & 439 & & $43 \%$ & N/A \\
\hline $\begin{array}{c}\text { PACE } \\
2009\end{array}$ & U.S & 474 & 7 & 361 & 106 & N/A & N/A \\
\hline $\begin{array}{c}\text { Hardisty } \\
\text { et al., } \\
2012\end{array}$ & $\begin{array}{c}\text { Australi } \\
\text { a }\end{array}$ & 450 & 7 & 356 & 87 & $53 \%$ & $0 \%$ \\
\hline $\begin{array}{c}\text { Agrawal, } \\
2014\end{array}$ & India & 584 & 129 & 455 & & $42 \%$ & N/A \\
\hline
\end{tabular}


Table 10: Life cycle Greenhouse gas emissions from unconventional natural gas $\left(\mathrm{kg} \mathrm{CO}_{2}\right.$ e/kWh) (Burnham et al., 2012; Hardisty et al., 2012; Heath et al., 2014; Howarth, 2014; Jiang et al., 2011; Laurenzi and Jersey, 2013; Stephenson et al., 2011)

\begin{tabular}{|c|c|c|c|c|c|c|c|}
\hline \multirow[b]{2}{*}{ Reference } & \multirow[b]{2}{*}{ Type } & \multicolumn{4}{|c|}{ Greenhouse gas emissions } & \multirow[b]{2}{*}{$\begin{array}{l}\text { Plant } \\
\text { efficie } \\
\text { ncy }\end{array}$} & \multirow[b]{2}{*}{$\begin{array}{c}\mathrm{CH}_{4} \\
\text { emission } \\
\text { rate }\end{array}$} \\
\hline & & $\begin{array}{l}\text { Life } \\
\text { cycle }\end{array}$ & $\begin{array}{c}\text { Upstrea } \\
\mathrm{m}\end{array}$ & $\begin{array}{c}\text { Combus } \\
\text { tion }\end{array}$ & $\begin{array}{l}\text { Liquefa } \\
\text { ction } \\
\text { and } \\
\text { transpor } \\
\mathrm{t}\end{array}$ & & \\
\hline Howarth, 2014 & $\begin{array}{c}\text { U.S Shale } \\
\text { gas }\end{array}$ & $\begin{array}{r}573.1 \sim 77 \\
2.1\end{array}$ & $\begin{array}{r}199.1 \sim 3 \\
98.1\end{array}$ & 374 & & $41.8 \%$ & $\begin{array}{c}3.6 \% \sim 7 . \\
9 \%\end{array}$ \\
\hline $\begin{array}{c}\text { Jiang et al., } \\
2011\end{array}$ & $\begin{array}{c}\text { U.S Shale } \\
\text { gas }\end{array}$ & 499 & 130 & 369 & & $50 \%$ & $2 \%$ \\
\hline $\begin{array}{c}\text { Burnham et al., } \\
2012\end{array}$ & $\begin{array}{c}\text { U.S Shale } \\
\text { gas }\end{array}$ & 599 & 130.2 & 468.8 & & $33.1 \%$ & $2.01 \%$ \\
\hline $\begin{array}{c}\text { Stephenson et } \\
\text { al., } 2011\end{array}$ & $\begin{array}{c}\text { U.S Shale } \\
\text { gas }\end{array}$ & 499.2 & 60.5 & 438.7 & & $43 \%$ & $0.66 \%$ \\
\hline $\begin{array}{l}\text { Heath et al., } \\
2014\end{array}$ & $\begin{array}{c}\text { U.S Shale } \\
\text { gas }\end{array}$ & 440 & 78 & 362 & & $51 \%$ & $1.3 \%$ \\
\hline $\begin{array}{c}\text { Laurenzi et al., } \\
2013\end{array}$ & $\begin{array}{c}\text { U.S Shale } \\
\text { gas }\end{array}$ & 466 & 103 & 363 & & $50 \%$ & $1.4 \%$ \\
\hline $\begin{array}{l}\text { Hardisty et al., } \\
2012\end{array}$ & $\begin{array}{c}\text { Australian } \\
\text { CSG }\end{array}$ & 540 & 62.1 & 405.5 & 72.4 & $53 \%$ & $0 \%$ \\
\hline
\end{tabular}


Table 11: Life cycle Greenhouse gas emissions from coal ( $\left.\mathrm{kg} \mathrm{CO}_{2}-\mathrm{e} / \mathrm{kWh}\right)$ (Burnham et al., 2012; Hardisty et al., 2012; Howarth, 2014; PACE, 2009)

\begin{tabular}{|c|c|c|c|c|c|c|c|}
\hline \multirow{2}{*}{$\begin{array}{l}\text { Mine } \\
\text { type }\end{array}$} & \multirow{2}{*}{ Reference } & \multirow{2}{*}{ Region } & \multicolumn{3}{|c|}{ Greenhouse gas emissions } & \multirow{2}{*}{$\begin{array}{c}\text { Plant } \\
\text { efficien } \\
\text { cy }\end{array}$} & \multirow{2}{*}{$\begin{array}{c}\mathrm{CH}_{4} \\
\text { emission } \\
\text { rate }\end{array}$} \\
\hline & & & $\begin{array}{l}\text { Life } \\
\text { cycle }\end{array}$ & $\begin{array}{c}\text { Upstre } \\
\text { am }\end{array}$ & $\begin{array}{c}\text { Combusti } \\
\text { on }\end{array}$ & & \\
\hline \multirow{4}{*}{ Surface } & Howarth, 2014 & U.S & 663 & 36 & 627 & $32.8 \%$ & N/A \\
\hline & \multirow{3}{*}{$\begin{array}{l}\text { Hardisty et al., } \\
\qquad 2012\end{array}$} & Austral & 1,026 & 61.3 & 964.7 & $33 \%$ & \multirow{3}{*}{$\begin{array}{c}0.0375 \mathrm{t} \\
\mathrm{CO}_{2} \text {-e per } \\
\text { ton of } \\
\text { coal }\end{array}$} \\
\hline & & $\begin{array}{c}\text { Austral } \\
\text { ia }\end{array}$ & 826 & 49.5 & 776.5 & $41 \%$ & \\
\hline & & $\begin{array}{c}\text { Austral } \\
\text { ia }\end{array}$ & 788 & 47.7 & 740.3 & $43 \%$ & \\
\hline $\begin{array}{c}\text { Undergr } \\
\text { ound }\end{array}$ & Howarth, 2014 & U.S & 700 & 72 & 627 & $32.8 \%$ & N/A \\
\hline \multirow[t]{2}{*}{ Mixed } & $\begin{array}{l}\text { Burnham et } \\
\text { al., } 2012\end{array}$ & U.S & $1,036.5$ & 52.1 & 984.4 & 34.1 & $\begin{array}{c}0.138 \mathrm{~g} \\
\mathrm{CH} 4 \text { per } \\
\mathrm{MJ} \text { of } \\
\text { coal }\end{array}$ \\
\hline & PACE, 2009 & U.S & 847.3 & 42.6 & 804.7 & N/A & N/A \\
\hline
\end{tabular}

In Australia, the environmental regulations vary from state to state (Figure 5). In particular, there are moratoria on hydro fracturing in Victoria and New South Wales (The Australian, 2014). Furthermore, the expansion of coal seam gas projects on the east coast has led to increased concerns over water pollution associated with all types of natural gas developments. Securing community acceptance for shale gas development is particularly challenging due to the lack of nationally harmonised regulatory regimes. As observed in the 
US, shale gas development will require collaboration amongst developers, governments and communities. Thus, gaining the "social licence to operate" is vital for both Australia and Europe to increase the investment attractiveness of shale gas development projects.

There are community concerns regarding the environmental impact of fracture stimulation. Ground water impacts, fugitive greenhouse gas emissions and minor earthquakes could arise due to the flow back of residual fluids from the drilling and stimulation processes. Therefore, operators and regulators need to be proactive in order to effectively engage with the community groups. More government funded research needs to be conducted to verify these effects and recommend good practice. The implementation of transparent mechanisms disclosing the types of chemicals used during the stimulation process and the adherence to well-defined regulatory procedures of well construction are important steps to winning community confidence. 


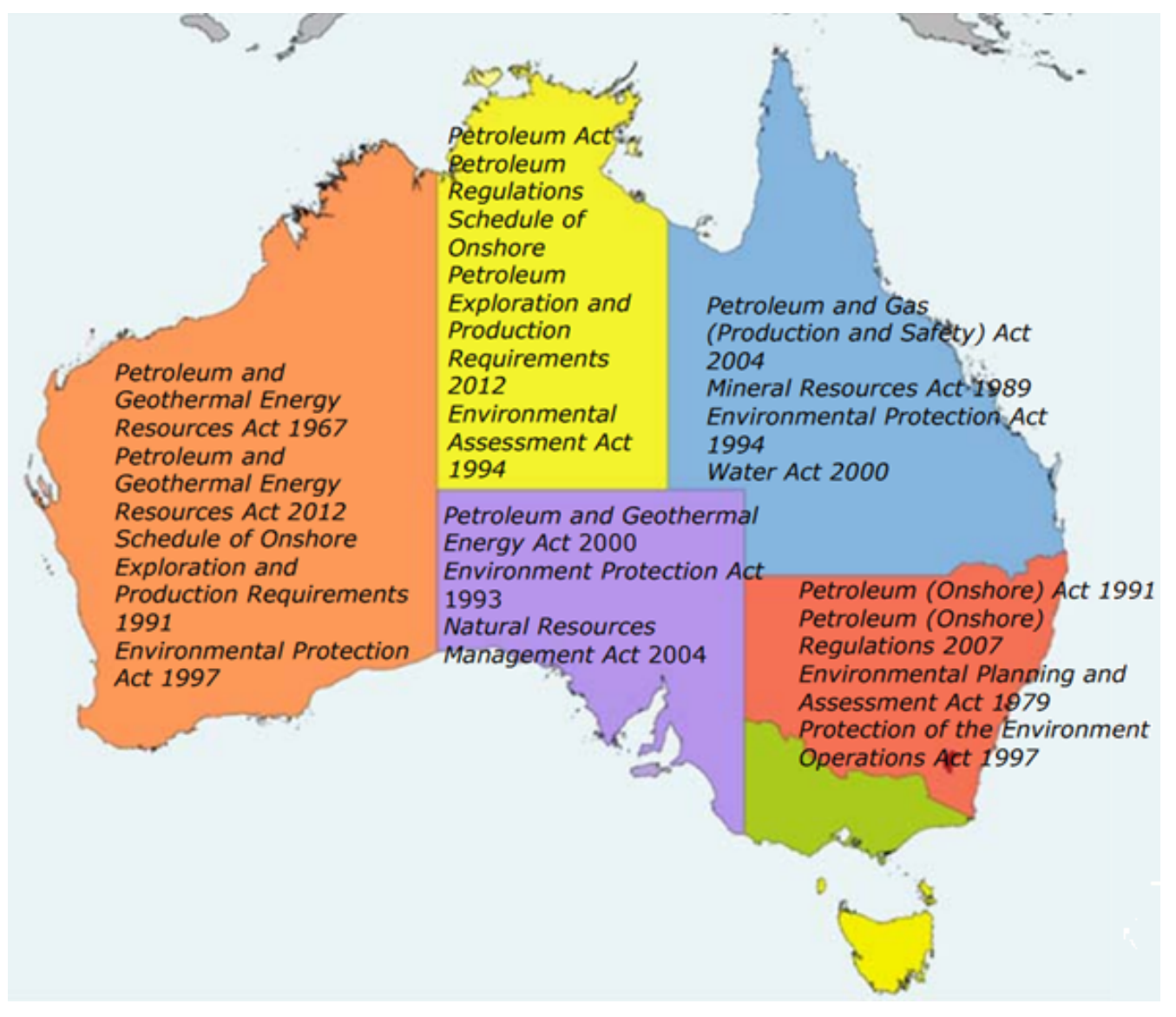

Figure 5. Governing regulatory regimes for natural gas development in Australia (Brockett, 2013)

4.4 Natural gas markets

Over the last decade, Australia has been successful in expanding LNG exports by attracting investments over $\$ 190$ billion, equivalent to $70 \%$ of total global LNG investments (Macquarie Securities, 2012), into its LNG industry with seven LNG mega-projects currently under construction and is set to overtake Qatar to become world's largest LNG exporter by the end of the decade (BP, 2014; Ripple, 2014). Currently, Australia is the world's third largest LNG exporter after Qatar and Malaysia, accounting for $9.4 \%$ of the total global LNG trade in 2012. As depicted by the IEA statistics, almost 100\% of Australian LNG has been exported to the Asian market (IEA, 2013). This is because Australia is strategically well positioned to cater to the well established markets of Japan, South Korea and Taiwan, as well 
as to emerging markets, such as China and India (Leather et al., 2013). Japan, Korea and Taiwan, have been driving Asian LNG demand since the 1960s by consistently absorbing more than $70 \%$ of the global LNG trade until the early 2000s (Jacobs, 2011). However, since then, China and India have been increasing their participation in the Asian LNG market. These two emerging markets have rapidly increased their LNG demand and had an $11.2 \%$ (36 Bcm) share of global LNG imports by 2012. Therefore, Australian LNG export prices are linked to JCC (Japan Customs-Cleared Crude) oil price, which is usually the contract LNG price for Japan, China and Korea (PAJ, 2015). Thus, Asian LNG markets will be key for the development of Australian shale gas resources. Based on the development costs, Asian gas market prices over \$ 15/ GJ could make it feasible to develop Australian shale gas resources. However, since the third quarter of 2014 , global crude oil prices have drastically declined to under \$50 a barrel, though, it has rebound to around \$60 per barrel in May,2015 (NASDAQ, 2015). This decline of oil prices have led to lower spot LNG prices in Japan (Table 12) (METI, 2015). It is forecasted that due to low oil prices, Australia is projected to incur a loss of $31 \$$ billion in 2017 - 18 , when estimated based on the 2013-2014 oil price levels (SMH, 2015). In addition, there are planned LNG exports from the US to be landed in the Asian markets from 2017 based on the Henry Hub prices. The US natural gas price is also on the decline with a price of around 2.5 \$/mmbtu in May, 2015 (EIA, 2015; Naturalgasintel, 2015). This could further put a declining pressure on the Asian LNG prices. Already, Australian natural gas development costs are in the top of the range compared to the US, Mozambique and Qatar (Core Energy, 2013). Therefore, in the current context global LNG prices don't have a positive outlook to develop emerging shale gas resources in Australia or Europe. Further, in Europe, cost of natural gas development is more than that of the renewables (Alberici et al., 2014). However, progressive development of these shale gas assets will still be important to enhance energy security. 
Table 12: Spot LNG contract prices of Japan (METI, 2015)

\begin{tabular}{|c|c|}
\hline Year/Month & Contract-based Price \\
\hline $2014 / 03$ & 18.3 \\
\hline $2014 / 04$ & 16.0 \\
\hline $2014 / 05$ & 14.8 \\
\hline $2014 / 06$ & 13.8 \\
\hline $2014 / 07$ & 11.8 \\
\hline $2014 / 08$ & 11.4 \\
\hline $2014 / 09$ & 13.2 \\
\hline $2014 / 10$ & 15.3 \\
\hline $2014 / 11$ & 14.4 \\
\hline $2014 / 12$ & 11.6 \\
\hline $2015 / 01$ & 10.2 \\
\hline $2015 / 02$ & 7.6 \\
\hline $2015 / 03$ & 8.0 \\
\hline
\end{tabular}

Therefore, whether or not to invest in shale gas developments as an important LNG resource is dependent on the development costs of other resources, as the cheaper alternatives in CSG, offshore conventional and onshore conventional gas resources, rather than the Australian domestic gas price, which was one of the main factors of the US shale gas revolution in the context of declining domestic gas resources (Core Energy, 2013; Stevens, 2010). As reflected from the US shale gas revolution, shale plays require increased activity levels and rapid well replacement procedures to benefit from the economies of scale. The distinctive differences of greater depths and the requirements of hydraulic fracturing at such depths will further delay developments.

\subsection{Policy implications}

Sound policies are critical to attracting investment for shale gas development, particularly in regionally isolated areas. Development risks in these harsh environments need to be reduced through the development of new technologies and the lowering of the direct costs. Novel emerging technologies, such as enhanced recovery using supercritical carbon dioxide, could lead to increased recovery ratios, particularly from clay rich formations (Godec et al., 2013). 
Up until now, US shales are often used as the prototype for shale and tight gas resource development elsewhere. However, achieving comparable recovery potentials is not feasible, particularly from non-marine shale formations, which are typically at greater depths and require higher upfront development costs.

A commercial shale play will require a large number of wells to be in operation simultaneously, with the ability to replace wells in a short time span. Shale wells have a high production rate in the initial years, followed by a rapid decline. Unless new technologies emerge that are capable of addressing the rapid decline curve, developing new commercial plays will be a considerable challenge, particularly for those at greater depths. Therefore, policies need to be considered that will attract all levels of developers and encourage the formation of local supply chains and services and decrease the development timeframe of a well. Currently, development of a deep shale well (more than 3000m) takes about 4-6 months for drilling and completion, as observed in Australia, compared to 1-2 months in the US (Stevens et al., 2013). This is mainly due to the widespread collaboration between developers and service providers in the US that has led to low development costs.

The fiscal policy regime in the US adapted as shale gas development progressed. In the initial period, $100 \%$ depreciation of well development costs in the first year was used to incentivise for small scale developers (Stevens, 2013). This reduced the investment risks of exploration and development and, hence, much well log data became available, enabling better identification of "sweet spots". However, shale gas development has also benefited immensely from the private mineral ownership. The added financial incentive of acquiring royalties has encouraged private owners to release lands for shale gas developments. This has 
led to such developments being widespread in the US, simultaneously fostering the growth of ancillary services and local supply chains.

\subsection{Policy recommendations}

If there are to be shale gas revolutions in Australia and Europe, all levels of developers need to be attracted towards shale gas development. The large scale portfolio-type developers with cheaper resource recovery assets will not set a high priority towards the development of expensive shale gas assets. Small scale developers with limited portfolio options or options only in shale gas will be more likely to develop these assets (The Australian Oil \& Gas Review, 2014). Therefore, the implementation of new policy options is critical to attract investment towards shale gas development. This study suggests four main options;

\section{Expedited depreciation mechanisms}

2. PRRT and income tax concessions

3. Play-based concessions and regulations

4. Government sponsored research studies and acquisition of well log data

\subsubsection{Expedited depreciation mechanisms}

The capital allowance method of providing $100 \%$ depreciation will attract more exploration investment in emerging shale gas developments (ACOLA, 2012), which will lead to more test wells being drilled. However, access to transit and processing infrastructure will also be required. Policy should not only be about rapid depreciation, but must also provide other incentives, such as third party access to pipeline infrastructure. 


\subsubsection{PRRT and income tax concessions}

As observed from the US shale plays, development plans will depend mainly on the prevailing gas prices (Kaiser, 2012). Therefore, investment in dry shale gas developments will be highly volatile. In order to create some market stability and to minimise investment risks, tax incentives could be awarded to developers for a prescribed duration, thereby encouraging investment in exploration over this period. However, such concessions give less security compared to rapid depreciation, when the geological challenges are considered.

\subsubsection{Play-based incentives}

Play-based mechanisms could be considered for a new shale play. This would potentially attract new developers to a prospective regional play simultaneously, keeping existing developers motivated. In the Canning basin of Western Australia, the shale plays are struggling to secure the necessary drilling rigs to initiate developments. Though there is substantial dry gas potential, the initial phase of development will only be focused on shale oil. However, if a percentage of the funds earned from the oil sales could be spent on the development of the necessary infrastructure for a future shale gas play to operate, such as the roads and processing facilities, then this would be an important development.

The investment in novel shale plays and the main infrastructure assets could be made tax free if the infrastructure is to be shared among new developers. Furthermore, the investment in regional shale plays could also be incentivised through the awarding of long term licenses. On the other hand, developers who do not deliver on agreed development programs will need their exploration licenses reviewed. However, imposition of direct penalties would not be advisable. Understanding the challenges of the geology, etc., of some of the plays requires 
more research to be carried out before commitments can be made on commercial development plans. The development of test wells will still be important to identify the sweet spots in a candidate shale resource basin and to develop a sufficient database of well logs and seismic data.

\subsubsection{Government sponsored research studies and test well log data}

As reflected in the US shale experience, the US shale gas revolution was almost 30 years in the making. Much research was conducted by independent institutions to develop the viable technologies and methodologies required for shale gas recovery (Armour Energy, 2013). Though Australia and Europe can inherit these technologies from the US, there will still need to be some customising to best suit the local non-marine lithologies. Most of the US shale plays are shallow, more brittle and of marine origin. Small-scale developers with limited budgets will not be able to spend on the basic research and development activities. If the large scale portfolio developers are not interested in the development of new technology, the government will need to take the initiative. As an added benefit to the national economy, the developed shale gas resources could be made available for domestic consumption.

\subsection{Conclusions}

This paper has focussed on an economic impact analysis of potential shale gas developments. Unconventional gas development is economically challenging compared to conventional recovery, as it utilizes hydraulic fracturing technology. However, the shale gas development challenges vary for Australia and Europe. In Europe, it is more to do with the direct development costs rather than the fiscal costs, whereas in Australia, it is more about the fiscal regime. Europe and Australia can benefit immensely by collective learning of the challenges concerning shale gas development. Incentives based on fiscal policy regimes will be needed 
to develop unconventional gas resources in the Australian context, whereas in the European context, the focus should be on reducing the direct development costs through incentivising local supply chains and increased activity levels. Energy security implications are also very different for Australia and Europe. As described in this study, Europe will need shale gas to fulfil primary energy needs, whereas Australia could use it as a swing supply source to maintain steady domestic gas prices with increasing LNG exports. Combinations of the proposed policy options need to be considered to successfully develop shale resources in Australia and Europe.

\section{References}

ACOLA, 2012. Interim report on shale gas financial modelling. Australian Council of Learned Academies, http://www.acola.org.au/PDF/SAF06Consultants/BurgessREPORT15Nov13.pdf (Accessed on $29 / 01 / 2015$ ).

ACOLA, 2013. Engineering energy: Unconventional gas production : A study of shale gas in Australia. Australian Council of Learned Academies, http://www.acola.org.au/PDF/SAF06FINAL/Final\%20Report\%20Engineering\%20Energy\%2 0June\%202013.pdf (Accessed on 14/01/2015).

AEA, 2012. Support to the identification of potential risks for the environment and human health arising from hydrocarbons operations involving hydraulic fracturing in Europe. European Commission DG Environment, http://ec.europa.eu/environment/integration/energy/pdf/fracking\%20study.pdf (Accessed on 14/01/2015).

Agarawal, A., Wei, Y., Holditch, S.A., 2012. A technical and economics study of completion techniques in five emergining US gas shales: A Woodford shale example, SPE Annual Technical Conference. Society of Petroleum Engineers, Florence, Italy.

Agrawal, K.K., Jain, S., Jain, A.K., Dahiya, S., 2014. Assessment of greenhouse gas emissions from coal and natural gas thermal power plants using life cycle approach. Int. J. Environ. Sci. Technol. (Tehran) 11, 1157-1164.

Alberici, S., Boeve, S., van Breevoort, P., Deng, Y., Förster, S., Gardiner, V., van Gastel, A., Grave, K., Groenenberg, H., de Jager, D., Klaassen, E., Pouwels, W., Smith, M., de Visser, E., Winkel, T., Wouters, K., 2014. Subsidies and costs of EU energy. European Commission, https://ec.europa.eu/energy/sites/ener/files/documents/ECOFYS\%202014\%20Subsidies\%20a nd\%20costs\%20of\%20EU\%20energy 11 Nov.pdf.

APIA, 2015. Facts and Figures. The Australian Pipeline Industry Association Ltd, http://www.apia.net.au/industry/facts-and-figures/ (Accessed on 20/01/2015).

Armour Energy, 2013. Australian unconventional oil and gas. Armour Energy, http://www.armourenergy.com.au/assets/downloads/investment research/2013/investment re 
search/09-2013_rfc-ambrian_australian-unconventional_oil_and_gas_report_pdf (Accessed on $15 / 08 / 2014$ ).

Arps, J.J., 1945. Analysis of Decline Curves. Transactions of the American Institute of Mining, Metallurgical and Petroleum Engineers 160, 228-247.

ATO, 2013. Prime cost and diminishing value methods, Deductions for business. Australian Taxation Office (ATO).

Beach Energy, 2011a. Encounter-1 well completion report, PEL218. Beach Energy Ltd, Adelaide, South Australia.

Beach Energy, 2011b. Holdfast-1 well completion report, PEL218. Beach Energy Ltd, Adelaide, South Australia.

Binnion, M., 2012. How the technical differences between shale gas and conventional gas projects lead to a new business model being required to be successful. Mar. Pet. Geol. 31, 37.

BP, 2014. BP Energy Outlook 2035. British Petroleum, http://www.bp.com/content/dam/bp/pdf/Energy-economics/Energy-

Outlook/Energy Outlook 2035 booklet.pdf (Accessed on 27/02/2015).

Brockett, R., 2013. Is Australia ready, willing and able to develop the next generation of unconventional gas resources?, APPEA onshore CSG conference 2013. Ashurst Australia, Adelaide, Australia.

Burnham, A., Han, J., Clark, C.E., Wang, M., Dunn, J.B., Palou-Rivera, I., 2012. Life-Cycle Greenhouse Gas Emissions of Shale Gas, Natural Gas, Coal, and Petroleum. Environ. Sci. Technol. 46, 619-627.

Cardott, B.J., 2006. Data relevant to Oklahoma gas shales, SWS/EMD Shale Gas Workshop. Oaklahoma Geological Survey, Midland, TX.

CityA.M., 2015. After UK shale triumph, Scotland announces moratorium on shale gas projects, $\quad$ http://www.cityam.com/208161/after-uk-shale-triumph-scotland-announcesmoratorium-shale-gas-projects (Accessed on 12/05/2015).

Core Energy, 2013. Projections of Gas Demand for LNG Export from Eastern and South Eastern Australia. Core Energy, http://aemo.com.au/Gas/Planning/ /media/Files/Other/planning/gsoo/2013/2013.09.04\%20L NG\%20Report.pdf.ashx (Accessed on 5/08/2014).

Curtis, J.B., 2002. Fractured shale-gas systems. American Association of Petroleum Geologists 86, 1921-1938.

Deparment of Energy and Climate Change, 2013. Resources vs Reserves, https://www.gov.uk/government/uploads/system/uploads/attachment_data/file/324555/Resou rces vs Reserves - note - 27-6-13-2.pdf (Accessed on 6.05.2015).

Dormer, M., 2013. World FLNG market forecast 2013-2019. Pipeline \& Gas Journal 240.

EIA, 2011a. Haynesville surpasses Barnett as the nation's leading shale play. U.S. Department of Energy, Washington DC, USA.

EIA, 2011b. Technology drives natural gas production growth from shale gas formations. U.S. Department of Energy, http://www.eia.gov/todayinenergy/detail.cfm?id=2170 (Accessed on 11/03/2015).

EIA, 2013. Technically Recoverable Shale Oil and Shale Gas Resources: An Assessment of 137 Shale Formations in 41 Countries Outside the United State. ARI, http://www.advres.com/pdf/A_EIA_ARI_2013\%20World\%20Shale\%20Gas\%20and\%20Shale\%20Oil\%20R esource\%20Assessment.pdf (Accessed on 29/01/2015).

EIA, 2014a. International Energy Outlook 2014. U.S. Department of Energy, http://www.eia.gov/forecasts/ieo/pdf/0484(2014).pdf (Accessed on 10/03/2015). 
EIA, 2014b. US gas pipelines. Energy Information Administration, http://www.eia.gov/pub/oil_gas/natural_gas/analysis_publications/ngpipeline/images/ngpipeli nes_map.jpg (Accessed on 27/02/2015).

EIA, 2015. Natural gas weekly update, http://www.eia.gov/naturalgas/weekly/ (Accessed on 6/05/2015).

EURACTIV, 2014. EU warms to shale gas in the wake of Crimea crisis, http://www.euractiv.com/sections/energy/eu-warms-shale-gas-wake-crimea-crisis-301142

(Accessed on 29/01/2015).

EY, 2013. Global oil and gas tax guide. Ernst \& Young, http://www.ey.com/Publication/vwLUAssets/2013_global_oil_and_gas_tax_guide/\$FILE/EY Oil and Gas 2013.pdf (Accessed on 22/01/2015).

Garratt, $\quad$ J., $2012 . \quad$ Methane hydrates. TALBOT, http://www.lmalloyds.com/CMDownload.aspx?ContentKey=5c20fbf2-aa00-45b8-9b08$\underline{3743 f 8 d 8 b f 29 \& C o n t e n t I t e m K e y=093 a 2 a c 2-c 245-4 c 61-8 d 42-d 2 a 35 d c b a 851}$ (Accessed on 12/05/2015).

Godec, M., Koperna, G., Petrusak, R., Oudinot, A., 2013. Potential for enhanced gas recovery and $\mathrm{CO}_{2}$ storage in the Marcellus Shale in the Eastern United States. Int. J. Coal Geol. 118, 95-104.

Goodman, M., 2012. Waterless fracking method targets natural gas industry's gaze, http://dfw.cbslocal.com/2012/01/12/waterless-fracking-method-target-for-natural-gasindustrys-gaze/ (Accessed on 11/05/2015).

Halliburton, 2008. U.S. Shale Gas : An unconventional resource. Unconventional challenges, http://www.shaleenergyinsider.com/wp-content/uploads/sites/11/2014/01/H063771.pdf

(Accessed on 11/03/2015).

Haluszczak, L.O., Rose, A.W., Kump, L.R., 2013. Geochemical evaluation of flowback brine from Marcellus gas wells in Pennsylvania, USA. Appl. Geochem. 28, 55-61.

Hardisty, P.E., Clark, T.S., Hynes, R.G., 2012. Life Cycle Greenhouse Gas Emissions from Electricity Generation: A Comparative Analysis of Australian Energy Sources. Energies 5, 872.

Heath, G., Meldrum, J., Fisher, N., Arent, D., Bazilian, M., 2014. Life cycle greenhouse gas emissions from Barnett Shale gas used to generate electricity. Journal of Unconventional Oil and Gas Resources 8, 46-55.

Hexion, 2009. What's working in the Fayetteville and Barnett Plays?, fracline. Hexion.

Howarth, R.W., 2014. A bridge to nowhere: methane emissions and the greenhouse gas footprint of natural gas. Energy Science \& Engineering 2, 47-60.

IEA, 2013. Natural Gas Information. OECD Publishing.

Jacobs, D., 2011. The global market for liquefied natural gas. Reserve Bank of Australia, http://www.rba.gov.au/publications/bulletin/2011/sep/pdf/bu-0911-3.pdf (Accessed on 27/07/2014).

Jiang, M., Griffin, W.M., Hendrickson, C., Jaramillo, P., VanBriesen, J., Venkatesh, A., 2011. Life cycle greenhouse gas emissions of Marcellus shale gas. Environ. Res. Lett. 6, 034014.

Kaiser, M.J., 2012. Haynesville shale play economic analysis. Journal of Petroleum Science and Engineering 82-83, 75-89.

King, R.F., 1993. Drilling Sideways. A Review of Horizontal Well Technology and Its Domestic Application. Energy Information Administration (EIA), Washington DC.

Kulkarni, P., 2011. An unconventional play with conventional E \& P constraints, Shale Energy - Developing the Woodford. Schlumberger, https://slb.com/ /media/Files/industry challenges/unconventional_gas/industry articles/2011 08_wo_woodford_shale_complexities.pdf (Accessed on 29/01/2015). 
Laurenzi, I.J., Jersey, G.R., 2013. Life Cycle Greenhouse Gas Emissions and Freshwater Consumption of Marcellus Shale Gas. Environ. Sci. Technol. 47, 4896-4903.

Leather, D.T.B., Bahadori, A., Nwaoha, C., Wood, D.A., 2013. A review of Australia's natural gas resources and their exploitation. J. Nat. Gas Sci. Eng. 10, 68-88.

Macquarie Securities, 2012. Australian LNG outlook Strangling the golden goose, http://www.macquarie.com.au/dafiles/Internet/mgl/au/apps/retail-

newsletter/docs/2012 12/AustralianLNGOutlook071212e.pdf (Accessed on 27/02/2015).

Mainwaring, J., 2013. Large tax breaks for UK shale gas. Rigzone, http://www.rigzone.com/news/oil gas/a/127861/Large Tax Breaks for UK Shale Gas (Accessed on 29/01/2015).

McGlade, C., Ekins, P., 2015. The geographical distribution of fossil fuels unused when limiting global warming to 2 [deg]C. Nature 517, 187-190.

Mckeon, M., 2011. Horizontal fracturing in shale plays, in: Halliburton (Ed.). Halliburton http://www.thepttc.org/workshops/eastern_062111/eastern_062111_McKeon.pdf (Accessed on 29/01/2015).

METI, 2015. Spot LNG price statistics. Ministry of Economy, Trade and Industry, http://www.meti.go.jp/english/statistics/sho/slng/ (Accessed on 6/05/2015).

Meurs, P.V., 2012. Shale Gas Taxatation Poland. Ernst \& Young, http://www.petrocash.com/documents/free/66602001.pdf (Accessed on 29/01/2015).

Mobbs, P., 2012. Shale gas: An analysis of UK policy and Cuadrilla resources exploration activities in Lancashire. Mobbs' Environmental Investigations, http://www.fraw.org.uk/mei/archive/shale_gas_in_lancashire.pdf (Accessed on 29/01/2015).

NASDAQ, 2015. Crude Oil, http://www.nasdaq.com/markets/crude-oil.aspx?timeframe=5y (Accessed on 6/05/2015).

Natural Gas Europe, 2012. ExxonMobil leaves Poland guessing. Natural Gas Europe, http://www.naturalgaseurope.com/exxonmobil-leaves-poland-shale-gas （ Accessed on 29/01/2015).

Natural Gas Europe, 2014. Total Joins Poland's Shale Exodus, http://www.naturalgaseurope.com/total-poland-shale-gas-exod (Accessed on 22/01/2015).

Naturalgasintel 2015.

NGIdata, http://www.naturalgasintel.com/data/data products/bidweek?location id=SLAHH\&region i $\mathrm{d}=$ south-louisiana (Accessed on 6/05/2015).

O’Brien, D., 2013. Longest lateral: Consol innovates efficiencies. Ohio Oil and Gas Energy Education Program (OOGEEP), http://oogeep.org/2013/11/longest-lateral-consol-innovatesefficiencies/ (Accessed on 11/03/2015).

ODNR, 2012. Preliminary report on the Northstar 1 Class II injection well and the seismic events in the Youngstown. Ohio Department of Natural Resources, http://media3.vindy.com/news/documents/2012/03/09/UICReport.pdf (Accessed on 12/05/2015).

PACE, 2009. Life Cycle Assessment of GHG Emissions from LNG and Coal Fired Generation Scenarios: Assumptions and Results Center for Liquefied Natural Gas, http://www.lngfacts.org/resources/LCA_Assumptions_LNG_and_Coal_Feb09.pdf (Accessed on $11 / 08 / 2015$ ).

PAJ, 2015. Oil statistics. Petroleum Association of Japan, http://www.paj.gr.jp/english/statis/ (Accessed on 6/05/2015).

Papadakis, G.A., 2005. Overview of pipelines in Europe - advantages and disadvantages. Technical University of Crete, http://www.unece.org/fileadmin/DAM/env/teia/water/pipeline/end_ve_papadakis.pdf (Accessed on 20/11/2014). 
Patterson, D., 2012. AIPN EA chapter event shale gas similarities between US \& Europe, http://www.moyesco.com/Portals/0/Publications/AIPN\%20Vienna\%20May\%202012_dee.pd $\underline{\mathrm{f}}$ (Accessed on 29/01/2015).

Rajtar, J.M., 2010. Shale gas - How is it developed? XTO Energy, http://yadda.icm.edu.pl/baztech/element/bwmeta1.element.baztech-article-AGHM-0024-0031 (Accessed on 29/01/2015).

Rawsthorn, K., 2013. Shale gas prospectivity potential. AWT International, http://www.acola.org.au/PDF/SAF06Consultants/AWTShale\%20Gas\%20Prospectivity\%20P otential\%20Jan2013.pdf (Accessed on 15.04.2014).

Regenauer-Lieb, K., 2014. Going deeper and hotter for cleaner, Unconventional energy and mineral resources, Australian Earth Science Convention 2014, New Castle, Australia.

Ripple, R.D., 2014. Australia emerging as top LNG supplier. Oil \& Gas Journal, http://www.ogj.com/articles/print/volume-112/issue-5/special-report-offshore-petroleumoperations/australia-emerging-as-top-lng-supplier.html (Accessed on 27/02/2015).

Ryder Scott, 2011. Promising DCA techniques emerge as widespread public debate focuses on shale gas forecasts, Reservoir Solutions, http://www.ryderscott.com/WP/wordpress/wpcontent/uploads/2014/03/news-2011-sep.pdf (Accessed on 12/03/2015).

SCER, 2013. Gas transmission pipeline capacity trading Standing Council on Energy and Resources Officials http://www.scer.gov.au/workstreams/energy-market-reform/gas-marketdevelopment/gtpct/ (Accessed on 5/08/2014).

Schulz, H.-M., Horsfield, B., 2010. Rock matrix as reservoir: mineralogy \& diagenesis.

Selley, R.C., 2012. UK shale gas: The story so far. Mar. Pet. Geol. 31, 100-109.

SMH, 2015. Tumbling oil prices could mean \$30b hit for Australia's LNG exports. The Sydney Morning Herald, http://www.smh.com.au/business/carbon-economy/tumbling-oilprices-could-mean-30b-hit-for-australias-lng-exports-20150126-12ydgx.html (Accessed on 6/05/2015).

Stamford, L., Azapagic, A., 2014. Life cycle environmental impacts of UK shale gas. ApEn 134, 506-518.

Stephenson, T., Valle, J.E., Riera-Palou, X., 2011. Modeling the Relative GHG Emissions of Conventional and Shale Gas Production. Environ. Sci. Technol. 45, 10757-10764.

Stevens, P., 2010. The shale gas revolution : Hype and reality. Chatham House, https://www.chathamhouse.org/sites/files/chathamhouse/public/Research/Energy,\%20Enviro nment\%20and\%20Development/r_0910stevens.pdf (Accessed on 5/8/2014).

Stevens, P., 2012. The 'shale gas revolution': Developments and changes. Chatham House.

Stevens, P., 2013. Shale Gas in the United Kingdom. Chatham House, http://www.chathamhouse.org/sites/files/chathamhouse/public/Research/Energy,\%20Environ ment\%20and\%20Development/131213shalegas.pdf (Accessed on 19/11/2014).

Stevens, P., Simons, S., De Silva, P.N.K., 2013. Shale gas in Australia: The policy options. University College London, http://www.ucl.ac.uk/australia/files/shale-gas-in-australia-greenpaper-final (Accessed on 20.01.2014).

Tay, A., 2014. The FLNG market is poised for growth. Maritime Reporter \& Engineering News, http://www.marinelink.com/news/market-poised-growth364439.aspx (Accessed on $10 / 03 / 2015)$.

Tedesco, 2012. Moomba-191 well completion report. Santos Energy Ltd, Adelaide, South Australia.

The Australian, 2014. Victoria extends ban to onshore fracking, http://www.theaustralian.com.au/business/mining-energy/victoria-extends-ban-to-onshorefracking/story-e6frg9df-1226934645155?nk=b9ba88310cbf3231b42f30c24db589a3

(Accessed on 26/11/2014). 
The Australian Oil \& Gas Review, 2014. Simplicity the key to junior's Success, http://www.keypetroleum.com.au/sites/keypetroleum.com.au/files/news_documents/April\%2 02014\%200il\%20and\%20Gas\%20Review\%20Feature\%20Story\%20Key\%20Petroleum.pdf (Accessed on 26/11/2014).

UK Government, 2013. Developing Onshore Shale Gas and Oil - Facts about 'Fracking', https://www.gov.uk/government/uploads/system/uploads/attachment_data/file/265972/Devel oping Onshore Shale Gas and Oil Facts about Fracking 131213.pdf (Accessed on 29/01/2015).

UK Government, 2014. Local councils to receive millions in business rates from shale gas developments, https://www.gov.uk/government/news/local-councils-to-receive-millions-inbusiness-rates-from-shale-gas-developments (Accessed on 29/01/2015).

Uliasz-Misiak, B., Przybycin, A., Winid, B., 2014. Shale and tight gas in Poland-legal and environmental issues. Energy Policy 65, 68-77.

USDOE, 2009. Modern shale gas development in the United States: A primer. United States Department of Energy, OK,73142.

Wang, Z., Krupnick, A.J., 2013. A retrospective review of shale gas development in the United States. Resources for the Future, http://www.rff.org/RFF/documents/RFF-DP-1312.pdf (Accessed on 25/08/2014).

Weijermars, R., 2013. Economic appraisal of shale gas plays in Continental Europe. Applied Energy, 106, 100-115.

World Energy Council, 2014. Energy sustainability index, http://www.worldenergy.org/data/sustainability-index/ (Accessed on 29/01/2015). 